\title{
En seks dager gammel pike med vektnedgang
}

Ved store vekttap hos nyfødte må både svikt i næringsinntak og patologiske tap vurderes som årsak. Grundig anamnese og utvalgte laboratorieprøver gir som regel diagnosen. Her beskrives en nyfødt pike som ble lagt inn med et betydelig vekttap, som krevde langvarig behandling og nøye overvåking.

Se kommentar side 869 og kunnskapsprøve på www.tidsskriftet.no/quiz

En seks dager gammel pike ble lagt inn ved vår avdeling på grunn av stor vektnedgang. Piken var første barn av friske foreldre. Barnet ble født ukomplisert åtte dager etter termindato etter et helt normalt svangerskap. Fødselsvekt var $3600 \mathrm{~g}$. Det var intet å bemerke ved førstedags barselundersøkelse. Mor og barn var innlagt ett og et halvt døgn ved pasienthotellet før hjemreise. Piken ble ikke veid ved hjemreise. På grunn av mellomliggende helg, kom piken til kontroll $i$ forbindelse med neonatale screeningprøver først sjette levedøgn. Hun hadde da vært fullammet. Vekten var denne dagen $2930 \mathrm{~g}$, altså en vektnedgang på $670 \mathrm{~g}$, eller nærmere $19 \%$ av fødselsvekten. Piken ble da lagt inn ved barneklinikken.

Nyfødte kan normalt ha en vektnedgang inntil $10 \%$ av fødselsvekten i løpet av den første leveuken. Dette er hovedsakelig betinget $i$ væsketap. Større vektnedgang ses ved manglende væskeinntak og ved patologiske tap i urin eller fra gastrointestinaltractus. Patologiske tap ses i praksis særlig ved salttapende tilstander som adrenogenitalt syndrom, tubulopatier og ved uttalte brekninger.

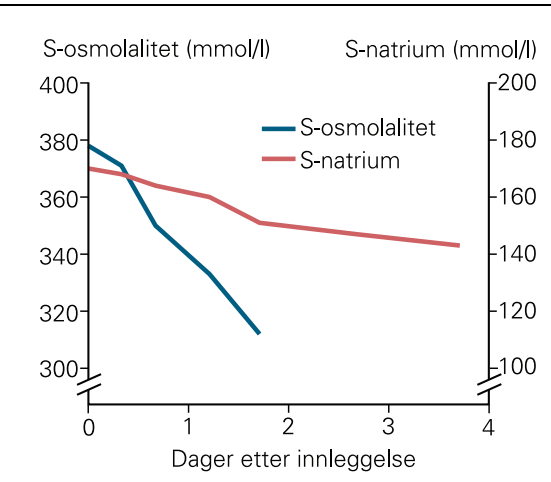

Figur 1 Fall i s-osmolalitet og s-natriumnivå i løpet av dagene piken var innlagt. Det var tilstrebet langsom normalisering av verdiene for å unngå utvikling av cerebralt ødem
Mor fortalte om et barn som alltid var sultent, og som lå mye ved brystet. Hun hadde inntrykk av at hun hadde hatt lite melk, men at det hadde kommet seg siste døgnet. Barnet gulpet nesten aldri. Barnet hadde kvittert mekonium i flere porsjoner, men avføringen hadde ikke endret karakter. Hun var noe usikker på hvor mye urin som var kvittert $i$ bleiene. Ved mottak ble piken oppfattet som kvikk. Man bemerket at hun var noe romskinnet, men fontanellen ble funnet normal i nivå, og det var lite ellers å bemerke ved klinisk undersøkelse. Hennes genitalia var normalt utseende, feminine uten tegn til unormal pigmentering, klitorishypertrofi eller annen maskulinisering. Blodprøver viste s-natrium $170 \mathrm{mmol} / \mathrm{l}$, s-kalium $3,6 \mathrm{mmol} / \mathrm{l}$, s-klorid $134 \mathrm{mmol} / \mathrm{l}$, hemoglobin $17,9 \mathrm{~g} / 100 \mathrm{ml}$, s-glukose 7,8 mmol/l, s-karbamid $30,0 \mathrm{mmol} / \mathrm{log}$ s-kreatinin $67 \mu \mathrm{mol} / \mathrm{l}$. Kapillær syre-basestatus viste $\mathrm{pH} 7,30, \mathrm{pCO}_{2} 5,5 \mathrm{kPa}$ og $\mathrm{BE}-5,8$. S-osmolalitet ble beregnet til $378 \mathrm{mmol} / \mathrm{l}$ (2 $\times$ s-natrium + s-karbamid + s-glukose) (1), altså kraftig forhøyet.

Kliniske funn og blodprøvebildet er forenlig med hyperton dehydrering. Ut fra anamnese og klinisk undersøklese synes det mest sannsynlig at dette er kommet på basis av for lite væskeinntak fordi mor har hatt for lite melk.

Det ble lagt inn venekanyle og gitt $75 \mathrm{ml}$ natriumklorid $9 \mathrm{mg} / \mathrm{ml}(20 \mathrm{ml} / \mathrm{kg}$ fødselsvekt) over en time som initial rehydrering. Piken kvitterte urin i bleien mot slutten av denne timen. Det ble deretter startet hydrering med en 1:1 blanding av glukose $50 \mathrm{mg} / \mathrm{ml}$ og natriumklorid $9 \mathrm{mg} / \mathrm{ml}$ tilsatt $20 \mathrm{mmol}$ kaliumklorid per liter. Denne blandingen har en konsentrasjon av natrium på $77 \mathrm{mmol} / \mathrm{l}$. Døgnbehovet av væske ble beregnet til $100 \mathrm{ml} / \mathrm{kg}$ fødselsvekt + rehydrering av $50 \%$ av væsketapet per døgn, altså om lag $500 \mathrm{ml} /$ døgn.

Det var fare for akutt sirkulatorisk kollaps med et så betydelig væsketap, og barnet fikk derfor initial væskeresuscitering. På grunn av fare for cerebralt ødem ved for raske svingninger i serum-osmolalitet, må både rehydrering og korrigering av osmolalitetsforstyrrelsen skje svært langsomt (2).

S-natriumnivået sank sakte med denne behandlingen (fig 1). Konsentrasjonen av snatrium, s-kalium, s-glukose og s-karbamid ble de første døgnene målt hver fjerde time. Piken ble under hele forløpet oppfattet som kvikk og kjekk. Hun ble måltidsveid etter amming, og hadde da tatt bare $5 \mathrm{ml}$. Mor pumpet seg for ytterligere $10 \mathrm{ml}$. Ammeteknikk ble gjennomgått med barnepleier, og det viste seg at mor hadde tilegnet seg en uhensiktsmessig teknikk som gjorde at barnet vanskelig kunne få tatt melk fra brystet. For å stimulere til melkeproduksjon fikk mor beskjed om å pumpe seg. Barnet fikk morsmelkerstatning på flaske i begrensede mengder (20 ml per måltid hver tredje time) for å unngå for store fall i s-osmolalitet.

Hypogalakti hos mor synes å være forklaringen på at piken er blitt dehydrert. Langsom rehydrering ga som ønsket et langsomt fall i serum osmolalitet, og piken viste ikke tegn til nevrologiske symptomer under korrigeringen. Vi valgte å gi piken peroral væskerestriksjon for å ha bedre kontroll over tilførsel, og dermed unngå for raske fall i osmolalitet.

Piken vedvarte å være klinisk kjekk under hele rehydreringsfasen. Dag 3 hadde s-natriumnivået falt under $160 \mathrm{mmol} / \mathrm{l}$, og man valgte da å la barnet drikke fritt. Hun tok raskt tilfredsstillende volumer på flaske. Til tross for iherdig brystpumping fikk moren ikke i gang tilstrekkelig melkeproduksjon, og barnet ble skrevet ut i velbefinnende med morsmelkerstatning som hovedernæring.

\section{Diskusjon}

Hyperton dehydrering hos spedbarn er en potensielt livstruende tilstand, med fare for tromboser, cerebrale blødninger og hypovolemisk sjokk (3). Nyfødte og små spedbarn som får utilstrekkelig væsketilførsel, har økt risiko for hyperton dehydrering på grunn av redusert evne til å konsentrere urin med påfølgende uhensiktsmessig stort renalt vanntap, i tillegg til at de har betydelige insensible vanntap gjennom hud og lunger (4). Primær hypogalakti hos mor er sjelden årsaken. Hypogalakti ser i hovedsak ut til å være betinget i dårlig tømming av brystene primært, med redusert melkeproduksjon som 
resultat (2). Hos vår pasient ble det avdekket uhensiktsmessig ammeteknikk som sannsynlig årsak.

Det har i det siste kommet flere rapporter om økende insidens av hyperton dehydrering hos nyfødte, blant annet fra Storbritannia (2), USA (5) og Danmark (6). Vi har ikke gjort noen systematisk opptelling, men vårt inntrykk er at vi ved vår avdeling også har stigende antall innleggelser av spedbarn med patologisk vekttap, og vi har flere eksempler på barn som har utviklet hyperton dehydrering.

Det har vært foreslått at økende andel ammende mødre er en mulig årsak til høyere insidens. I Norge er det en lite sannsynlig forklaring, all den tid dette er en tilstand som oppstår i løpet av de første to leveuker, og ammefrekvensen blant norske mødre en uke etter nedkomst angis å ha vært over $90 \%$ siden 1858 (7). De siste årene har varigheten på barselopphold gått ned. Nyfødte har et fysiologisk vekttap de første levedøgn, der de fleste når laveste vekt rundt 3.-4. levedøgn før vekten begynner å stige igjen. De fleste barn i vårt distrikt skrives nå ut fra barselavdelingen i løpet av de første to levedøgn, altså mens de fortsatt går ned i vekt, og før mor har kommet ordentlig i gang med melkeproduksjon. Hvis da barna ikke veies i løpet av de påfølgende døgn, vil det være vanskelig å fange opp mødrene med sviktende amming. Veiing er den eneste sikre måten å avdekke stort vekttap. Oppførsel hos barnet, gulsott, urin- og avføringsfrekvens er ikke sensitivt nok til å fange opp risikobarn (8). Vår pasient var lite preget klinisk av å være dehydrert, til tross for betydelig vanntap. Tidlig veiing etter hjemreise er derfor påkrevd for å fange opp risikobarn og forhindre alvorlig dehydrering.

Behandling av hyperton dehydrering krever langsom korrigering av væsketap og hyperosmolalitet. Ved for raskt fall i osmola- litet er det fare for utvikling av cerebralt ødem og kramper. Målet er å redusere s-natriumnivået med ikke mer enn $10 \mathrm{mmol} /$ døgn (eller s-osmolalitet med ikke mer enn 20-24 mmol/døgn) (9). Ved uttalt dehydrering eller påvirket sirkulasjon bør man initialt gi volumterapi i form av et væskestøt med natriumklorid $9 \mathrm{mg} / \mathrm{ml}$ eller Ringer-acetat tilsvarende $15-20 \mathrm{ml} / \mathrm{kg}$ over 30 minutter til en time. Ved svært uttalt hyperosmolalitet (s-natrium $>175 \mathrm{mmol} / \mathrm{l}$ ), vil disse løsningene være hypotone, med fare for for raskt fall i osmolalitet, og det er da foreslått at man tilsetter natriumklorid $30 \mathrm{mg} / \mathrm{ml}(513$ mmol natrium per liter) til man får en konsentrasjon som er bare $10-15 \mathrm{mmol}$ lavere i natriumkonsentrasjon enn serum-natrium (10). Videre væsketerapi beregnes ut fra et behov på $100 \mathrm{ml} / \mathrm{kg} /$ døgn + korrigering av beregnet væsketap over 48 timer. Initial væskeresuscitering skal regnes inn i dette væskeregnskapet. Glukose $50 \mathrm{mg} / \mathrm{ml}$ tilsatt $70 \mathrm{mmol} / \mathrm{l}$ natriumklorid og $20 \mathrm{mmol} / \mathrm{l} \mathrm{ka-}$ liumklorid er en hensiktsmessig blanding, eventuelt kan man gi blanding av glukose $50 \mathrm{mg} / \mathrm{ml}$ og natriumklorid $9 \mathrm{mg} / \mathrm{ml} \mathrm{i}$ forholdet 1:1 med kaliumtilsetninger. Ved uttalt hyperosmolalitet, eller ved raskt fall $i$ natriumnivå bør man øke natriumkonsentrasjon i hydreringsvæsken. Serum-natrium, -kalium, -klorid og -glukose bør monitoreres hver 2.-4. time. Konsentrasjonen av karbamid (til beregning av serum-osmolalitet) og kalsium bør også følges med flere målinger i døgnet. Tilsetninger i hydreringsvæsken må korrigeres fortløpende ved for raskt fall i osmolalitet eller andre avvik (9). Enteral ernæring må også tas med i væske- og osmolalitetsregnskapet. Vi valgte å begrense enteral ernæring til barnet de første døgnene for å unngå for høy tilførsel av hypoton væske.

Gitt at man ikke har fått sjokkutvikling, cerebralt ødem eller vaskulære katastrofer i forløpet av en neonatal hyperton dehydre- ring på grunn av hypogalakti, synes faren for sekvele å være liten. I en studie fra California fant man ikke signifikant forskjell i nevropsykologiske tester hos fem år gamle barn som hadde vært hypertont dehydrert som spedbarn i forhold til en kontrollgruppe (11).

\section{Erling Tjora \\ erling.tjora@helse-bergen.no \\ Hallvard Reigstad \\ Barneklinikken \\ Haukeland universitetssykehus \\ 5021 Bergen}

Oppgitte interessekonflikter: Ingen

\section{Litteratur}

1. Kumar S, Berl T. Sodium. Lancet 1998; 358: 220-8.

2. Laing $\mid A$, Wong $C M$. Hypernatraemia in the first few days: is the incidence rising? Arch Dis Child Fetal Neonatal Ed 2002; 87: 158-62.

3. Kaplan JA, Siegler RW, Schmunk GA. Fatal hyper natremic dehydration in exclusively breast-fed newborn infants due to maternal lactation failure. Am J Forens Med Pathol 1998; 19: 19-22.

4. Modi N. Avoiding hypernatraemic dehydration in healthy term infants. Arch Dis Child 2007; 92: 474-5.

5. Moritz ML, Manole MD, Bogen DL et al. Breastfeeding-associated hypernatremia: are we missing the diagnosis? Pediatrics 2005; 116: e343-7.

6. Reilev M, Børch K, Pryds OA. Hypernatriæmisk dehydrering hos nyfødte - hvorfor stigende incidens? Ugeskr Læger 2007; 169: 1227-31.

7. Eide I, Heiberg E, Helsing E et al. Ammeunders $\varnothing$ kelsen år 2000. Rapport. Oslo: Helsetilsynet, 2003.

8. Macdonald PD, Ross SRM, Grant L et al. Neonatal weight loss in breast and formula fed infants. Arch Dis Child Fetal Neonatal Ed 2003; 88: 472-6.

9. Norsk barnelegeforening. Akuttveileder i pediatri 2006; Kapittel 1.6.2. www.barnelegeforeningen.no (10.3.2009)

10. Schwaderer AL, Schwartz GJ. Treating hyper natremic dehydration. Pediatr Rev 2005; 26 $148-50$.

11. Escobar GJ, Liljestrand P. Hudes ES et al. Five-year neurodevelopmental outcome of neonatal dehydration. J Pediatr 2007; 151: 127-33.

Manuskriptet ble mottatt 20.11. 2008 og godkjent 26.2. 2009. Medisinsk redaktør Odd Terje Brustugun.

\section{Kommentar}

\section{Veiing er viktig i barseltiden}

Nesten alle mødre brysternærer barnet når de forlater barselavdelingen. Men medaljen har en bakside. Utilstrekkelige melkemengder kan i løpet av få dager lede til en kritisk hyperton dehydrering (1), som foranstående kasuistikk er et lærerikt eksempel på. Tilstanden kan ende i sirkulatorisk kollaps og død, ev. cerebrale skader pga. tromboser og infarkter (2). Forekomsten er trolig økende, muligens relatert til korte barselopphold med inadekvat ammetrening (3). Umoden nyrefunksjon hos nyfødte (bedre evne til saltretensjon enn vannretensjon) kombinert med et høyt insensibelt vanntap er sannsynlige patofysiologiske mekanismer for tilstanden (1). Jeg vil påpeke tre viktige punkter innen diagnostikk, behandling og profylakse.

Det er viktig å huske at hyperton dehydrering ikke gir det samme kliniske bildet som isoton eller hypoton dehydrering. Pga. intracellulært ødem mangler ofte klassiske dehydreringstegn som halonerte øyne og innsunken fontanell. Det er først og fremst et betydelig vekttap $(10-30 \%$ av fødselsvekten) som er indikator på dehydreringen. Et for- høyet s-natriumnivå (> $150 \mathrm{mmol} / \mathrm{l}$ ) viser at denne er hyperton.

Behandlingen må forhindre utvikling av et alvorlig hjerneødem. Ved behov for intravenøs væske er det derfor viktig å anvende løsninger med et relativt høyt natriuminnhold, og sikte mot en gradvis normalisering av barnets s-natriumnivå. Virker barnet sykt (sirkulatorisk kompromittert), gis volumekspansjon med $15-20 \mathrm{ml} / \mathrm{kg} 0,9 \% \mathrm{NaCl}$ i løpet av 30-60 minutter (ev. raskere). Dette følges opp med intravenøs rehydrering over de nærmeste par døgn, slik forfatterne utmerket beskriver. 